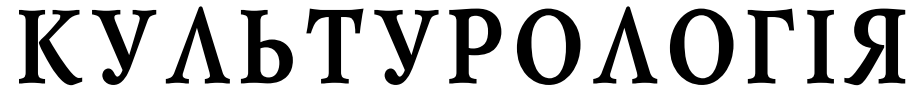

DOI: https://doi.org/10.32839/2304-5809/2021-3-91-29

УДК 130.2-055.2

Ляшенко Л.Л.

Національний педагогічний університет імені М.П. Драгоманова

\section{ПОСТАТЬ ЖІНКИ В РІЗНИХ КУЛЬТУРАХ ЯК ПРЕДМЕТ НАУКОВОГО АНАЛІЗУ: ДОКУМЕНТАЛЬНИЙ ТА ХУДОЖНІЙ АСПЕКТ}

Анотація. Мета роботи: розглянути постать жінки в різних культурах як предмет наукового аналізу на матеріалі документальних та художніх літературних творів (Савако Арійосі, О. Козуля, М. Дочинець та М. Москвіна), що досі не отримали достатнього наукового вивчення. Під час написання статті було використано аналітичний метод, метод опису, порівняння, біографізму та узагальнення. Наукова новизна полягає у введені в науковий обіг нового фактологічного матеріалу, в тому числі підкреслення перспектив наукового аналізу ряду художніх та документальних творів з метою вивчення постаті жінки. Запропонований аналіз виявив значне опертя на документальні матеріали. У розглянутих джерелах відтворено широкий контекст (культурний, соціальний, політичний), що оточував постаті героїнь, а також прослідковано вплив різних обставин на їхні життеві долі. Доведено, що ці твори мають не лише художне, або наукове значення, але світоглядне та виховне. Художній стиль викладу та поєднання документальних фактів із вигаданими допомогли авторам створити яскравий, насичений образ жінки та привернути до неї увагу читачів.

Ключові слова: образ жінки, родина, тема роду, покоління, жанр роману, історичні, соціальні, політичні фрактори, культурний контекст.

Lyashenko Lidiya

National Pedagogical Dragomanov University

\section{THE FIGURE OF A WOMAN IN DIFFERENT CULTURES AS A SUBJECT OF SCIENTIFIC ANALYSIS: DOCUMENTARY AND ARTISTIC ASPECT}

Summary. In the twentieth century the plane for intensive change was a rethinking of the role of women in the family, society and culture in general. The woman, who has traditionally been the guardian of the family hearth, educator of children and creator of family comfort for thousands of years, gradually began to try on other roles, successfully mastering them. The theme of the genus in general and its individual members of different generations, in particular, reveals the idea of the role of women. It occupies a prominent place in world and Ukrainian literature. The comparison of the life destinies of women of «neighboring» generations mothers and daughters, grandchildren and grandmothers, - is the most interesting, especially when they fall into the most controversial historical periods, such as the turn of the nineteenth and twentieth centuries, and the twentieth and twenty-first centuries. Purpose of Article: to consider the figure of a woman in different cultures as a subject of scientific analysis on the basis of documentary and artistic literary works (Sawako Ariyoshi, O. Kozulya, M. Dochynets and M. Moskvina), which have not yet received sufficient scientific study. The analytical method, the method of description, comparison, biography and generalization were used during the writing of the article. The scientific novelty lies in the introduction of new factual material into scientific circulation, including the emphasis on the prospects of scientific analysis of a number of works of art and documentaries in order to study the figure of a woman. The proposed analysis revealed significant reliance on documentary materials. In the considered sources the wide context (cultural, social, political) surrounding figures of heroines is reproduced, and also influence of various circumstances on their life destinies is traced. It is proved that these works have not only artistic or scientific significance, but worldview and educational. The artistic style of presentation and the combination of documentary facts with fictional ones helped the authors to create a bright, rich image of a woman and attract readers' attention to her.

Keywords: the figure of a woman, family, generation, novel genre, historical, social, political factors, cultural context.

$\Pi^{2}$ остановка проблеми. XXI ст., яке ха-
рактеризують індроммщйне та постіндустріальне суспільство, що фрактично стали його синонімами, поглинаючи новітні технології, впевнено крокуе вперед, часто не бажаючи озирнутися назад. Однак неможливо побудувати майбутнє, не враховуючи досвіду минулих поколінь, не переосмисливши минулі події та світоглядні парадигми попередніх епох. У національному та світовому суспільстві у XX ст. площиною для інтенсивних змін стало переосмислення ролі жінки у родині, суспільстві та культурі загалом.
Жінка, яка традиційно тисячоліттями була хранителькою сімейного вогнища, вихователькою дітей та творцем сімейного затишку, потроху почала примірювати на себе інші ролі. Вдало їх опановуючи, жінка відчинила для себе новий, широкий світ профресій, занять, подій, розкриваючи свій багатобічний потенціал та досягаючи вагомих результатів. Недивно, що ці трансформації ролі жінки та їі відкриття нової себе привернули увагу митців. "Нова» жінка стає героєм літературних творів, в тому числі романів, а їі життеві перипетії - основою сюжетних ліній. 
Окрім того, зростаючий інтерес до постаті жінки у різних іпостасях спостерігається у науковій думщі. Ряд українських вчених (Д. АндросоваБайда, Л. Буряк, М. Гук, О. Кісь, О. Кривоший, О. Мамроцька, Н. Мудра, О. Нестерцова-Собакарь, Т. Орлова, Л. Смоляр, О. Стрельник, О. Стяжкіна, С. Філоненко, Т. Шарова, Д. Юсип, Г. Янішевська) присвячують свої праці біографріям та зображенню життя жінок певного історичного періоду (Київська Русь, період Другої Світової війни, межа XX та XXI ст.), постатял жінок в різних сфбеpax діяльності (жінки-історики, жінки-мисткині, жінки-правительки, жінки-воїни, жінки-будівничі), правовій проблематииі (X-XVII ст., друга половина XIX - поч. XX ст., XX ст. після революції 1917 р.,) розгляду жінки в бееліністичному та гендерному контексті (жінки-селянки, жінки-письменнищі, жінки в українському суспільстві початку XXI ст..). Проводяться наукові конференції, присвячені аналізу постатей українських жінок різних епох та напрямків діяльності - в науці та технологіях, в науці та освіті, в політиці та державотворенні, - а також проблелам збереження репродуктивного здоров'я жінок, «проблемам просторової дискримінації та забезпечення права різних соиіальних груп на міський простір" [4] (Київ, 1993 р.; Дніпропетровськ, 1996; Київ, 2011; Ніжин, 2019 р.; Вінниця, 2019; Київ, 2020 р. та ін.). Наведені публікації, що широко розкривають проблему постаті жінки, вказують на актуальність обраної теми.

Аналіз останніх досліджень і публікацій. Розкриває ідею ролі жінок у родині, серед інших, тема роду взагалі та окремих його представників різних поколінь, зокрема, що посідае чільне місце у світовій та українській літературі. Прикладами є романи «Анна Кареніна» (1873-1877 рр.) Лева Толстого, «Сім’я Буссардель» (1944р.) Філіппа Еріа, «Палаци Вассаров» (1960р.) Ганса Леберехта, "Сага про Форсайтів" Джона Голсуорсі (1906-1921), «Сто років самотності» Габріеля Гарсіа Маркеса (1967р.), «Вербовая дощечка» Теодозії Зарівни (2008р.) та багато інших. У всесвітньо відомому творі Л. Толстого однаково блискуче зображено життя жінки та її внутрішній світ. Роман $\Phi$. Еріа репрезентуе життя чотирьох поколінь, із вражаючою майстерністю відкриваючи цілу епоху - XIX ст., - в яку читач занурюеться з головою. Долям родини у складні роки революційних подій початку XX ст. присвячено роман $Г$. Леберехта. Цикл творів Д. Голсуорі невипадково здобув міжнародне визнання: все в цих творах - i продуманий сюжет, i зображення буденного життя численних героїв, і мова викладання, що захоплюе, і яскраво зображені події, які буквально встають перед очима читача, - створено на високому художньому рівні. Всесвітньо відомий твір Г. Маркеса демонструе історію одного села, простежуючи період від його утворення до його занепаду. У романі Т. Зарівни поеднано біографічний, психологічний, історичний, культурний та соціальний аспекти розповіді.

Спільним для усіх перелічених творів $е$ існування реальних прототипів головних героїв, посилання на історичні події, які мали місце в житті авторів, що майстерно переплетені з їхньою франтазією та вигадкою. У наведених романах відзначаемо, що особливо привабливим виявляеться образ жінки, розкриття ії̈ внутрішнього світу і духовного життя, що трансформуеться під неминучим впливом зовнішніх фракторів - історичних, соціальних, політичних, економічних та культурних. Окрім того, хочемо підкреслити, що постать жінки в контексті різних культур також представляе великий інтерес, адже дозволяе проводити певні паралелі, порівняння, аналізувати розбіжності у ставленні до жінки, замислюватися над її правами та обов'язками.

Виділення не вирішених раніше частин загальної проблеми. Найцікавішим є співставлення життевих доль жінок «сусідніх» поколінь матері та дочки, онуки та бабусі, - що припадають на найсуперечливіші історичні періоди, наприклад, межу XIX та XX ст., а також XX та XXI ст. Слід відзначити, що ступінь популярності та відомості творів, присвячених розгляду родинних історій, є доволі різним: від світової популярності та мільйонних тиражів до лише локального визнання. Тому нижче ми приділимо увагу саме тим творам, які не отримали достатнього висвітлення у наукових публікаціях, але дуже глибоко розкривають означену проблематику постаті жінки у різних культурах: художній роман Савако Арійосі «Кінокава» (1964р.), науково-документальна праця Олеся Козулі «Жінки в історії України» (1992 р.), художньо-документальна робота Мирослава Дочинця «Руки і душа та інші невигадані жіночі історії» (2015р.), художньо-документальний роман Марини Москвіної «Кріо» (2017р.). Наведені роботи розкривають проблему постаті жінки у японській, українській та російській культурах та створені авторами, котрі, будучи «всередині» цих культур, знають їх до найменших дрібниць.

Мета статті - розглянути постать жінки в різних культурах як предмет наукового аналізу на матеріалі документальних та художніх творів, що досі не отримали достатнього наукового вивчення.

Виклад основного матеріалу дослідження. Літературним твором, в якому розкривається образ жінки в контексті теми поколінь, е роман «Кінокава" (1964р.) [1] одніеї з найяскравіших японських письменниць XX ст. - Савако Арійосі (1931-1984 pp.).

Сюжет роману розгортається навколо жінок трьох поколінь, чиї долі припадають на період 3 кінця XIX (1897р.) до 60-х pp. XX ст. Саме ці шістдесят років детально зображеного життя головної героїні - японки Хани Кімото, від її підготовки до одруження і до іï вісімдесятиріччя, створюють центральну сюжетну лінію роману. Однак авторка не лише майстерно та детально відтворюе усе багатство життя японської дівчини до та після одруження, а також у різні вікові періоди. Вона також плавно вплітає в розповідь жіночі образи попереднього покоління (бабусі Тойоно Кімото, - котра виховала онуку) та двох наступних (дочки Фуміо Матані та онуки Ханако Матані), і тому читач мимоволі стає свідком життя жінок декількох поколінь, що течуть плавно та природно, немов та ріка Кінокава, яка символізуе в романі найбільшу цінність - рід, - поеднуючи усіх своїх представників в єдине, неподільне щіле, наймогутнішу стихію. Невипадково саме назва ріки обрана в якості заголовка книги.

Вибір жіночих постатей як центральних для роману викликаний, по-перше, тим, що зміни у житті жінки не лише в японській, але і у всіх інших 
культурах, після одруження та народження дітей $\epsilon$ найочевиднішими. Ще одним фрактором, що зумовив зацікавленість Савако Арійосі жіночими образами, стало те, що, не дивлячись на величезний розрив у традиційно дозволеній участі в соціальному житті жінок та чоловіків в японській культурі, що існував аж до соціально-політичних перетворень та появи різного роду соціальнодемократичних партій i рухів першої третини XX ст., які в кінці кінців все ж таки почали змінювати свідомість японців, саме по материнській лінії споконвіку вівся родовід, об'єднуючи через одруження різні роди та перетікаючи у різні землі, 3 одного на інший берег могутньої Кінокави.

Можливо, саметому цяідея, хочаіненав'язливо, але з'являється на самому початку оповіді, коли настоятель храму, в якому мала за традицією розпочатися весільна церемонія Хани, звертає увагу молодої дівчини на один з легендарних епізодів, пов'язаних із іменем Кукая (посмертне ім'я Кобо Дайсі), глави одного з напрямків японського буддизму, та його матері. Настоятель розповідає, що одного разу «Кукай з'явився уві сні Кісіну і сказав: "Замість того, щоб підносити мені хвалу десять разів, дев'ять разів звертайтеся із молитвою до моєї матері"» [1, с. 9]. Знайомство із головною героїнею розпочинається невипадково саме з цього дня, коли їі бабуся піднімаеться 3 нею у храм матері Кобо Дайсі, яка вважається заступницею усіх породіль. Саме цей шлях і символізуе вічну жіночу долю - від одруження до старіння через народження майбутніх представників свого роду.

Роман читається на одному подиху, настільки невимушеним є його мова, цікавими постають деталі японських традицій, з любов'ю та ніжністю зображене буденне життя японців - представників різних класів та поколінь. Важливим фактором, що надає роману актуальності, $є$ підкреслення не просто зв'язку, а навіть визначального впливу на долі як окремих представників японського народу, так і цілого народу бурхливих політичних змін та соціальних перетворень, що впродовж XX ст. відбувалися безупинно та мали величезні масштаби, накочуючи, мов сніжний ком, на століттями налагоджене, спокійне життя японців та буквально змітаючи віками усталений побутовий лад.

Все це відбивалося не тільки на особливостях зовнішнього життя японців, але і на їхньому світогляді, ідеях, переконаннях, поглядах та взагалі світосприйнятті - всьому тому, що ми називаємо особистим внутрішнім світом. У цьому морі різнорівневих соціально-культурно-світоглядно-особистісних змін яскраво зображено усе багатство міжособистісного життя: протиріччя між представниками різних поколінь (вічні складнощі стосунків між батьками та дітьми), несхожість та навіть полярність поглядів та темпераментів дітей, що виховувалися в одній родині; фрормування стосунків між чоловіком та жінкою в контексті особливостей японського традиційного шлюбу (за домовленістю) та поява принципово нового для японської культури шлюбу по коханню, що починає руйнувати традиційну роль жінки, котра пасивно очікує рішення батьків, щодо кандидата на роль свого майбутнього чоловіка.

I абсолютно логічною у романі $е$ подібність характерів Хани та її онуки Ханако, між якими лежить не лише вікова відстань, але й більш могутня сила - глобальні соціально-політичні та історичні перетворення, що, наче землетрус, зруйнували стару японську культуру і спорудили нову. І ця нова культура і нова Японія, яку так не розуміла і якій чинила опір Хана, з одного боку, і яка була рідною і звичною для її онуки, з іншого, виховала останню, що стала ближче духовно до бабусі, ніж їі мати до своєї матері у свій час.

Це вічне повернення до власного роду, як до найціннішого, невичерпного джерела, що не просто надає сили для життя, для боротьби, але й символізує ідею єднання окремих людей, як ланок. в єдиний цілий і безкінечний ланцюг, $є$ центральною та найпотужнішою думкою, яку і намагалася висловити у своему дивовижному романі Савако Арійосі. I цей рід, як ми вже зазначали, одночасно символічно та цілком реально схожий на величезну, часом галасливу, а часом тиху, часом спокійну, а іноді смертельно небезпечну річку, що знаходиться у вічному русі та $є$ непідвладною стихією, що підкоряється тільки природнім, і ні в якому разі людським, законам.

Прикладом наукового та документального дослідження, присвяченого постаті жінки в українській культурі, є робота українського дослідника О. Козулі “Жінки в історії України» [5]. Відзначимо, що у передмові автор абсолютно логічно спростовуе тезу німецького фрілософра А. Шопенгауера про те, що жінка «не призначена для надто великої праці - ні духовної, ні тілесної <...> та не створена для вищих страждань, радощів і могутнього прояву сил» [цит. за: 5, с. 5], зазначаючи, що у вітчизняній історії немало з українських жінок «в культурно-освітній, політичній, і навіть військовій діяльності не тільки не поступалися перед чоловіками, а й перевершували їх. Але завжди на різних життевих шляхах і перехрестях українська жінка стояла на боці милосердя, несла велику любов і сімейне тепло» [5, с. 5]. Як справедливо зазначає автор, у долях наведених в книзі найвизначніших українських жінок «віддзеркалюеться доля всіх наших жінок на протязі славної і багатостраждальної історії України» [5, с. 5], адже вони творили українську історію, культуру та загалом націю нарівні із чоловіками.

Це княгиня Ольга, Анна Ярославна (майбутня королева Франції), Свпраксія Всеволодівна та Анна Всеволодівна (онуки Ярослава Мудрого), Добродія-Евпраксія-Зоя (онука Володимира Мономаха), збірний образ козачки, Настя-Роксолана (дружина одного з наймогутніших султанів Османської імперіі), Марія Заньковецька, письменниці Людмила Старицька-Черняхівська та Зінаїда Тулуб, героїні війни з фашистською Німеччиною Тетяна Маркус та Катерина Зеленко, а також інші видатні українські жінки, які своєю самовідданою працею у різних галузях (духовна нива, утвердження православної церкви, виховання, наука, розповсюдження освіти та переписування книжок, формування національних видів мистецтва та літератури) сприяли становленню духовності, культури та науки української нащї.

В той самий час не лише перелічені видатні жінки, але й мільйони інших жінок, особливо у часи воєн, отримували невтішні звістки про смерть своїх чоловіків у боях, як це сталося колись із княгинею Ольгою. Однак тільки язичнищький звичай кривавої помсти став причиною жорстокої розправи кня- 
гині із древлянами. Християнські ж заповіді проповідують зовсім іншу, протилежну за своєю суттю поведінку вдови після насильнищької смерті чоловіка. Водночас варто зазначити, що ця помста княгині Ольги була останнім вчинком, що лежав у площині язичнищького світобачення та світорозуміння.

Як стверджує легенда, після поради віщого старця покаятися за вчинену древлянам жорстоку помсту, Ольга змінилася до невпізнання. Тепер вона дбала про укріплення князівської влади шляхом проведення ряду адміністративних редрорм, що призвело до економічного зростання Київської Русі та збільшення їі політичної ваги на міжнародній арені.

Хрещення княгині Ольги О. Козуля абсолютно виправдано вважає доленосним вчинком не тільки особисто для неї, але і для всієї Русі та майбутньої історії України.

Як відомо, однією з життевих місій християнинаслужителя $є$ побудова Церкви (не як матеріального храму, а як духовного об'еднання християн). Однак варто пам'ятати, що починалося усе від княгині Ольги, котра побудувала першу, але далеко не єдину дерев'яну церкву святої Codpiï, на місці якої (після iї знищення пожежею) Ярослав Мудрий побудував відомий Софійський собор - першу кам'яну християнську споруду Київської Русі. I ще підкреслимо, що за період правління княгині Ольги, після прийняття нею християнства, Київська держава не воювала 3 жодною сусідньою державою.

Продовжила місію побудови церков одна з дочок Ярослава Мудрого. Відомим є фракт, що у часи Ярослава Мудрого «Київ ряснів понад 400 церквами» [5, с. 17]. Анна Ярославна, ставши королевою Франціi, заснувала там храм та каплицю та, як відомо, дуже добре знала Святе Писання. Підтримала цю традицію онука Ярослава Мудрого, Анна Всеволодівна, котра заснувала Андріївський монастир у Києві та жіночу школу, що стала першою у своєму роді не лише у Київській Русі, але і в Свропі.

Можливо, джерело сили волі українських жінок пояснюеться історією, що сорормувала їхні певні генетичні риси ще з часів Київської держави, - про це пише О. Козуля:

«Постійна відсутність чоловіка - козака, що пішов на Січ, в похід або загинув, сприяла фрормуванню в українській жінці стійкості, незалежного характеру. Але тернами був укритий цей шлях до незалежності. За відсутності чоловіка треба було виховувати дітей, сіяти й жати хліб, самій вирішувати важкі й важливі справи. За будь-яку ціну треба було вижити, не схибити. Все це підносило на вищий щабель їі власну гідність і авторитет, сприяло формуванню самостійності й волелюбства» [5, с. 365$]$.

Одна з героїнь розвідки О. Козулі - українська письменниця Зінаїда Тулуб. Вона так само чітко усвідомлювала свою мету у житті - писати історію українського народу (мова йде про історичний роман «Людолови» (1934-1937; 1956 рр.)), - і будьщо намагалася її виконати. О. Козуля так зображуе важку пращю письменника, котрий береться за відтворення історичного минулого: «Важко переоцінити ті великі зусилля по виявленню, систематизації, дослідженню зібраних матеріалів, котрі лягли в основу цього твору, блискучу мову, стрімкість, фрілософрічну заглибленість сюжету, панорамність відтворення соціальних процесів в Україні в першій половині XVII століття.
Цим романом вона повернула українському читачеві забуті сторінки трагічної і водночас героїчної історії України. Тієї історії, на яку український народ уже не мав права. Зінаїда Тулуб створила масштабне художне полотно саме в часи сталінського лихоліття, коли будь-який спогад про те, що існуе така велика, колись горда і волелюбна нація, вважався за злочин. Тому, доторкнувшись живодайних джерел свого народу, його історії, авторка лишалася під ідеологічним тиском тоталітарної більшовицької системи. Талант їі і хист були міцно затиснуті в лабетах соціалістичного реалізму» [5, с. 129-130].

Однак мала значення не лише тематика, але й час, коли письменниця звернулася до ціеї непопулярної теми. Будучи засудженою за цей роман на 19 (!) років, 10 з яких вона провела у таборах, письменниця після повернення, в першу чергу, взялася за завершення розпочатої справи, відчуваючи, що часу в неї лишилося обмаль.

Таким чином, жінки у книзі О. Козулі, кожна по-своєму, проходять важкий життевий шлях, сповнений духовних та фрізичних випробувань, та лишаються вірними кожна своєму покликанню - хто письменництву, хто живопису, хто служінню, а хто захисту Батьківщини.

Певним продовженням згаданої роботи О. Козулі є робота українського письменника 3 міста Мукачево Мирослава Дочинця «Руки і душа та інші невигадані жіночі історії» [див.: 3]. Адже в монографрї зображено історії жінок України від початку XX ст. до сучасності.

Ця книга не просто продовжуе створення портретів українських жінок різних історичних епох, але й переслідуе ту саму мету: відтворення їхніх складних та суперечливих життевих доль у бурхливому та перенасиченому випробуваннями ХХ ст. Водночас, як свідчать наведені О. Козулею та М. Дочинцем в їхніх книгах історії, «рецепт» перемоги та стійкості жінок був і лишається один, як у часи Київської Русі, так і сьогодні. Це «робота, праведне життя і молитва» [див.: 3, с. 15].

Героїнями книги М. Дочинця стають цілителька, масажистка, колишні аристократка та арештантка, черниця та інші жінки, які в результаті численних редрорм XX ст. - економічних, соціальних і політичних, - стають буквально викинутими «за борт» суспільства.

Так, колишня аристократка мусить збирати каштани, щоб ними топити пічку, та готувати на продаж страви з лісових равликів, щоб заробити на життя. Колишня золотошукачка, що із руйнуванням Радянського союзу втратила разом із чоловіком усі свої заощадження на важкій роботі в Якутії, згадує це із посмішкою та радіє, що вдалося-таки заробити мінімальну пенсію. Ще одна бабуся, в жилах якої тече румунська, польська та єврейська кров, розповідає нечувану історію про те, як у молоді роки потрапила спочатку у концтабір, а потім в лабораторію в якості учасниці експерименту... Інша жінка, втративши власну дитину, радіє подарованому Богом після цієї втрати сину та мріє віддячити Богу, побудувавши Церкву.

Жінки у наведених М. Дочинцем оповіданнях демонструють своїм життям, що милосердя, любов, молитва, смиренність, віра та любов до своєї справи є тими чеснотами, рисами особистості i, зрештою, метою життя, які не застарівають ніколи. Вони ста- 
ють натхненням і наповненням людського життя, витягуючи з мороку обставин і наближуючи до Бога навіть ті долі, що, здавалося, зовсім занапастилися.

Підсумовуючи огляд згаданої праці, наголосимо, що «робота, праведне життя і молитва» не є шляхом тільки вузького кола обраних та хрещених Духом Святим, які присвятили своє життя служінню Богу, але $є$ універсальним шляхом до внутрішнього спокою, згоди із самим собою та пошуку щастя та сенсу свого буття.

У романі «Кріо» сучасної російської письменниці М. Москвіної [див.: 2], побудованому на архівних даних про членів іï родини та доповненому і збагаченому авторською франтазією, наводиться історія роду через зображення окремих яскравих героїв: Стєши, що пише книгу про свого батька, самого батька та багатьох інших. У своєму інтерв'ю, говорячи про даний роман та взагалі про свою творчість, авторка наголошуе на декількох важливих моментах.

По-перше, М. Москвіна підкреслюе, що практично у всіх їі літературних творах в тому чи іншому вигляді з'являються реальні історії, сюжети та образи з її життя та історії їі сім’і: «Я відчуваю живу кров і тепле дихання свого древа, енергію роду. Як величезна зграя птахів перелітних, ці образи кочують з книги до книги, змінюючи обличчя, характери, долі, сплітаючись та утворюючи над головою сімейний космос» [2].

I другий момент полягає у тому, що саме через усвідомлення власного зв'язку із своїм родом, переосмислення усіх родових подій та сімейної історії письменнищя починає краще розуміти саму себе: «І всюди я намагаюсь зрозуміти, хто людина у царстві тіней, яку я вважаю собою, скільком людям довелося елементарно вижити, зустрітися та покохати одне одного, щоб я з'явилася на світ. В їхніх долях так само переплетені життя багатьох поколінь» [2].

Нерідко ідея написати книгу про рід приходить комусь 3 представників цього роду, хто добре знає видатних пращурів і розуміе доленосне значення їхніх постатей для усіеї великої сім’ї нащадків. Так було 3 книгою М. Москвіної (ідея книги на основі архівних даних належить їі матері).

Матеріалами, що лягли в основу книги М. Москвіної, є численні посвідчення, мандати, інші документи, власний револьвер дідуся, його щоденники, фотографії, листи, малюнки та вірші.
I усі ці документи та артефракти їі мати дбайливо збирала та зберігала протягом багатьох років. Зазвичай така потужна праця, як збирання та опрацювання сімейних архівів, триває певний час, і у випадку книги «Кріо» авторка наводить термін у сім років.

Відтворюючи життеві долі та шляхи своїх пращурів, сюжет роману «Кріо» «мандрує» на величезні відстані, слідуючи за своїми героями. I в результаті долі, події різних людей, котрі зустрічаються та стають представниками одного роду, ніби сплітаються у клубок, утворюючи родову єдність, неподільну та міцну.

Наукова новизна статті полягає у введені в науковий обіг нового фрактологічного матеріалу, в тому числі підкреслення перспектив наукового вивчення ряду художніх та документальних творів 3 метою вивчення постаті жінки.

Висновки 3 даного дослідження та перспективи. Постать жінки є привабливим образом для письменників і науковців. У кожній культурі формуеться власна літературна спадщина, що посвоєму розкриває зазначену тему у різних аспектах: науковому, художньому та документальному. Запропонований аналіз виявив значне опертя на документальні матеріали у ряді добре відомих художніх творів (Ф. Еріа, Т. Зарівна, Г. Леберехт та ін.), а також у працях Савако Арійосі, О. Козулі, М. Дочинця та М. Москвіної. Цінність вибраних для дослідження творів у процесі вивчення проблематики постаті жінки полягає у наступному. По-перше, у роботах відтворено широкий контекст (культурний, соціальний, політичний), що оточував постаті героїнь, а також прослідковано вплив різних обставин на їхні життеві долі. По-друге, щі твори мають не лише художне, або наукове значення (у випадку наукових публікацій), але світоглядне та виховне, адже відображають світогляд певної епохи та знайомлять читача із відповідними цінностями та нормами. I, нарешті, варто підкреслити, що художній стиль викладу та поєднання документальних фрактів із вигаданими часто допомагають створити яскравий, насичений образ жінки та привернути до неї увагу читачів. На наш погляд, саме культурний контекст для розгляду постаті жінки здатний створити широкі перспективи для подальших досліджень ціеї вкрай важливої та надзвичайно актуальної теми.

\section{Список літератури:}

1. Ариёси Савако. Кинокава : Роман / Пер. Н. В. Кузьминовой. Москва : ЗАО Центрполиграф, 2006. 350 с.

2. Галкина В. Мир явно движется по кругу, а очеловеченная, живая история не подвержена фальсификации. Литературная газета. № 41 (6662), 10-16 октября 2018. С. 8.

3. Дочинець Мирослав. Руки і душа та інші невигадані жіночі історії. Мукачево : Карпатська вежа, 2015.128 с.

4. Друга міжнародна конференція «Модерністки. Насильство в архітектурі та міському просторі». URL: https://urbanforms.org.ua/projects/modernistki-conference-2017/ (дата звернення: 15.03.2021).

5. Козуля Олесь. Жінки в історії України. Київ : Український центр духовної культури, 1993. 256 с.

\section{References:}

1. Ariyoshi Sawako (2006) Kinokawa: novel / Interpreter N. V. Kuzminova. Moscow: ZAO: Tsentrpoligraph, 350 p. (in Russian)

2. Galkina V. (2018) The world is clearly moving in a circle, and humanized, living history is not subject to falsification. Literary newspaper, no. 41 (6662), October, 10-16, p. 8. (in Russian)

3. Dochynetc Miroslav (2015) Hands and soul and other uninvented women's stories. Mukachevo: Karpatska vezha, 128 p. (in Ukrainian)

4. Second International Conference «Modernists. Violence in architecture and urban space» (2017). URL: https://urbanforms.org.ua/projects/modernistki-conference-2017/ (date of last appeal: March, 15, 2021.) (in Ukrainian)

5. Kozulya Oles (1993) Women in the history of Ukraine. Kyiv: Ukrainian Center of Spiritual Culture, 256 p. (in Ukrainian) 